\title{
Pathogenesis of chronic Chagas cardiomyopathy: the role of coronary microvascular derangements
}

\author{
José Antonio Marin-Neto ${ }^{[1]}$, Marcus Vinicius Simões ${ }^{[1]}$ and Anis Rassi Junior ${ }^{[2]}$
}

[1]. Divisão de Cardiologia, Hospital das Clínicas, Faculdade de Medicina de Ribeirão Preto, Universidade de São Paulo, Ribeirão Preto, SP. [2]. Hospital Anis Rassi, Goiânia, GO.

\begin{abstract}
There is ample experimental and clinical evidence of functional and structural microvascular abnormalities occurring in patients with Chagas cardiomyopathy, possibly due to the inflammatory process and/or autonomic disturbances caused by Trypanosoma cruzi infection. Those microvascular derangements are likely to constitute at least an ancillary factor that potentiates and amplifies the chronic inflammation in myocardial tissue. It is possible to devise appropriate therapeutic interventions aimed at reverting or slowing the progression of the microvascular abnormalities to positively affect the natural history of Chagas cardiomyopathy.
\end{abstract}

Keywords: Chagas disease. Microvascular coronary disease. Pathogenesis.

\section{INTRODUCTION}

One hundred years after the discovery of Chagas disease, the pathogenesis of chronic Chagas cardiomyopathy (CCC) is still open to debate ${ }^{1}$. Nevertheless, there is both experimental and clinical evidence of coronary microvascular disturbances leading to ischemic myocardial damage in animals infected with Trypanosoma cruzi and in patients with chronic Chagas heart disease ${ }^{2}$.

\section{EVIDENCE FROM HISTOPATHOLOGY STUDIES IN HUMANS}

Necroscopic studies of patients who died in the acute phase of Chagas disease showed perivascular inflammatory changes that were considered to be involved in causing myocardial damage ${ }^{3}$. Further necropsy studies of chronic Chagas patients also described extensive vascular lesions, with obstruction of the small intramural coronary artery branches due to intimal proliferation and arteriole wall thickening. In addition, the myocardial fibers topographically related to these vascular lesions presented myocytolytic necrosis, a type of cell death related to ischemic injury ${ }^{4}$. The authors concluded that microvascular ischemia is directly involved in the genesis of the fundamental histopathologic pattern of $\mathrm{CCC}$, consisting of diffuse focal myocarditis associated with myocytolysis and subsequent reparative fibrosis ${ }^{5}$. Another type of structural derangement is related to the rarefaction of the microvessels into the myocardium. This process of decapillarization was thought

Address to: Prof. José Antonio Marin-Neto. Divisão de Cardiologia/HC/ FM-RP/USP. Av. dos Bandeirantes 3900, 14048-900 Ribeirão Preto, SP, Brasil.

Phone/Fax: 55 16 3633-4010/3633-0869

e-mail: marin_neto@yahoo.com

Received 7 February 2013

Accepted 26 June 2013 to be related to extraluminal compression and was shown to be topographically related to foci of myocytolysis, as demonstrated by a necroscopic radiological study of Chagas disease patients using a coronary injection of an opaque medium ${ }^{6}$. Vascular changes characterized by a decreased density of coronary vessels were confirmed in another postmortem radiological study of patients with proven Chagas disease ${ }^{7}$.

Microvascular abnormalities due to the extensive basement membrane thickening of capillaries were also thought to be associated with the focal diffuse myocytolysis observed in both necroscopic studies and biopsy specimens ${ }^{8}$. Other independent investigations confirmed the occurrence of structural changes in the microvascular coronary tree, with both abnormal dilation and constriction leading to myocardial damage in patients with Chagas disease ${ }^{9-12}$. In addition, considering that the focal distribution of cell necrosis and subsequent reparative interstitial fibrosis observed in Chagas disease follows a pattern similar to that described in experimental models of ischemia and reperfusion, transient microvascular ischemic disturbances of low intensity and short duration have been postulated to cause ischemic myocardial damage and to ultimately lead to the development of cardiomyopathy ${ }^{13,14}$. Coalescent microinfarctions have also been implicated in the genesis of the typical Chagas disease-related ventricular aneurysms that are postulated to occur in watershed coronary areas ${ }^{15}$. Further necropsy studies in humans correlated the presence of an apical aneurysm with scores proportional to the myocardial mass and coronary perfusion and concluded that ischemic factors could be involved in the genesis of the peculiar lesion of Chagas cardiomyopathy ${ }^{16}$. Following the demonstration that isoproterenol infusion in experimental animals without T. cruzi infection led to the formation of ventricular aneurysms similar to those found in Chagas disease, the neurogenic theory of chronic Chagas disease posited an abnormality in the autonomic control of the coronary circulation that would 
lead to overactivity of the sympathetic system, causing chronic myocardial ischemia ${ }^{17}$. These investigators also performed a macroscopic study in necropsied patients with Chagas disease and described an increased capacity of the coronary artery bed. The authors concluded that these findings would lend further support to the neurogenic pathogenesis concept ${ }^{18}$. However, this issue is controversial because an in vivo study using quantitative coronary angiography in Chagas heart disease patients with chest pain and no obstructive coronary artery disease (CAD) in the subepicardial vessels showed that the baseline coronary artery diameter and tonus were not related to the degree of autonomic dysfunction ${ }^{19}$.

\section{EVIDENCE FROM ANIMAL MODELS OF T. CRUZI INFECTION AND IN VITRO STUDIES}

Early studies in the 1970s used histopathologic and histoenzymologic methods to compare the myocardial lesions found in Wistar rats chronically infected with $T$. cruzi with those lesions detected in other rats submitted to repeated injections of isoproterenol. The researchers found that there was marked histoenzymatic similarity between the lesions found in both experimental models and concluded that the myocardial damage described in the rats with $T$. cruzi infection could be caused by ischemia triggered by excessive stimulation with catecholamines ${ }^{20}$. Using histochemical methods in mice chronically infected with $T$. cruzi, several independent investigators have described microcirculatory derangements that cause ischemia associated with occlusive platelet thrombi in small epicardial and intramural coronary arteries ${ }^{21,22}$. In the same experimental model, other microvascular derangements were detected, such as focal areas of vascular constriction and endothelial microvascular proliferation ${ }^{23}$. Similar alterations have been found in other models of experimental T. cruzi infection, including the development of typical ventricular aneurysms ${ }^{24}$. The mechanisms responsible for occlusive platelet thrombosis and microcirculatory spasm were directly related to the $T$. cruzi infection causing endothelial cell damage ${ }^{25}$ and indirectly related to the interaction of the endothelium with immune effector cells ${ }^{26,27}$. In vitro studies of $T$. cruzi infection of human umbilical vein endothelium cells showed increased production of endothelin. This potent vasoconstrictor mediated arteriolar spasm and impaired cyclic adenosine monophosphate (AMP) metabolism, thus impairing AMP's protective role against platelet adhesion to and aggregation along the vascular wall ${ }^{28,29}$. Trypomastigote forms of $T$. cruzi also produce a neuraminidase that may remove sialic acid from the surface of mammalian myocardial and endothelial cells ${ }^{30}$. The loss of this protective component of the endothelial surface may be associated with platelet aggregation and microvascular thrombosis. These abnormal findings were corroborated by increased production of thromboxane-A2 and enhanced platelet adherence and aggregation in an experimental murine model of $T$. cruzi infection ${ }^{31}$. The increased production of cytokines by inflammatory cells is also likely to contribute to microvascular abnormal reactivity in experimental models of Chagas heart disease $\mathrm{e}^{32}$. These abnormalities have been shown to be reverted by verapamil, a vasodilatory calcium channel blocker with antiplatelet properties, thus attenuating myocardial aggression and, more importantly, leading to increased survival of mice acutely infected with $T$. $c r u z i^{33}$. These findings were also corroborated by direct in vivo visualization of the murine cremaster vascular bed. This model showed that animals infected with $T$. cruzi had arterioles with segmental areas of spasm and reduced flow velocity; these abnormalities, which were not observed in control mice, were also antagonized by treatment with verapamil ${ }^{34}$. Finally, disturbed molecular mechanisms are thought to modify the function of the microcirculation in Chagas cardiomyopathy. For example, calreticulin, a calcium-binding protein that is also present in the parasite, was shown to interfere with modulation of the complement system and inhibit angiogenesis ${ }^{35}$.

\section{EVIDENCE FROM CLINICAL STUDIES}

Myocardial ischemic manifestations are commonly detected in patients with Chagas heart disease and may contribute to the pathogenesis of the disease's complex pathophysiology. Atypical angina pectoris is a common complaint in T. cruziinfected patients ${ }^{36}$. The characteristics of the chest pain are slightly consistent with ischemic cardiac pain (location and character) but typically have no relation to effort and no relief by the use of nitrates. Most of these patients have concomitant transient or definite ST-T changes on a 12-lead electrocardiogram (ECG) and abnormal Q waves compatible with electrically inactive left ventricular (LV) areas ${ }^{37,38}$. More rarely, patients may present with a clinical picture that mimics an acute coronary syndrome ${ }^{37}$. Similar to coronary heart disease, segmental LV wall motion abnormalities are common in patients with chronic Chagas disease and are even occasionally detected when the LV chamber is already globally dilated ${ }^{39,40}$. Despite the occurrence of all of these manifestations, suggesting the presence of myocardial ischemia, catheter-based coronary angiography in Chagas' cardiomyopathy nearly invariably demonstrates the absence of significant obstructive coronary disease at the epicardial level ${ }^{36-41}$.

\section{CORONARY MACROVASCULAR DYSFUNCTION}

Although the angiographic appearance of the coronary arteries is normal in most patients with chest pain and documented T. cruzi infection, impairment of the regulation of the coronary circulation may occur at the macrovascular level. The possibility of coronary spasm was postulated as causing acute myocardial infarction in Chagas disease patients with normal coronary arteries ${ }^{42}$. However, other investigators showed no evidence of coronary artery spasm in any of 31 consecutive patients with Chagas' disease who exhibited precordial pain severe enough to warrant cardiac catheterization, despite the specific stimulus of the forced hyperventilation test

Consistent with the experimental studies discussed above, impairment of endothelium-dependent coronary vasodilatation in response to acetylcholine has been reported in patients with Chagas' heart disease, but these patients had a preserved response to the non-endothelium-dependent effect of adenosine $e^{43}$. In another study, Chagas patients with angina that was atypical but severe enough to warrant coronary angiography had blunted vasomotor epicardial responses to hyperventilation and isosorbide dinitrate ${ }^{44}$. These combined findings suggest that abnormal coronary flow regulation may be caused by endothelial 
and non-endothelial dysfunction in Chagas patients with chest pain and angiographically normal epicardial coronary arteries. However, there are no conclusive data showing that these functional macrovascular derangements have any relevant impact on the pathogenesis of Chagas cardiomyopathy.

\section{CORONARY MICROVASCULAR DYSFUNCTION}

Since the 1970s, the pioneering work of Emilio Kuschnir and his collaborators in Córdoba, Argentina, employing primitive nuclear medicine methods (the measurement of global myocardial flow with 86-rubidium), showed that chronic Chagas patients, similar to patients with $\mathrm{CAD}$, exhibited a reduction in myocardial perfusion at rest and during physical exercise in comparison with normal individuals ${ }^{45-47}$. Several other investigations have subsequently described striking myocardial perfusion abnormalities in Chagas disease patients with angiographically normal coronary arteries, thus supporting the concept of abnormal flow regulation that essentially occurs at the microvascular level ${ }^{41,48,49}$. Using 201-thallium stress-redistribution myocardial perfusion scintigraphy (MPS), one of these investigations demonstrated at least one perfusion defect in all 23 chagasic patients studied ${ }^{48}$.

Fixed defects, connoting myocardial fibrosis, were found in myocardial segments exhibiting akinesis or dyskinesis, and stress-induced, reversible myocardial ischemia was detected in LV segments with less severe wall motion impairment in $8(35 \%)$ patients $^{48}$. These findings were confirmed and extended by a further study of 37 patients with various stages of Chagas heart disease ${ }^{49}$. Regional MPS was also assessed by the use of 201-thallium with single-photon emission computed tomography (SPECT), this time focusing on the topographic correlation between segmental myocardial perfusion abnormalities and regional LV dysfunction. Perfusion defects (fixed, paradoxical and reversible) were observed in most (78\%) of the patients, and a significant topographic correlation was observed between perfusion disturbances and wall motion abnormalities predominating in the apical and inferior-posterior LV segments. Reversible, stressinduced myocardial perfusion defects were detected in segments exhibiting normal wall motion in $5(42 \%)$ of 12 Chagas disease patients who otherwise had no evidence of myocardial disease (possibly with the indeterminate form of the disease) ${ }^{49}$. Of note, these reversible ischemic defects were mostly observed in the apical and inferior-posterior LV segments, i.e., the same regions in which regional contractile dysfunction is more frequently found in later stages of Chagas cardiomyopathy ${ }^{49}$. An additional intriguing finding was that marked sympathetic denervation, as evaluated by myocardial scintigraphy with iodine-123-metaiodobenzylguanidine (MIBG), was demonstrated in topographic association with the presence of perfusion abnormalities in patients with less advanced deterioration of LV function ${ }^{49}$.

This finding suggests that the sympathetic denervation and perfusion derangements may be pathophysiologically linked and that these events occur at early stages in the natural course of Chagas cardiomyopathy, before the installation of typical segmental contractile dysfunction. This suggestion may indeed be the case based on a more recent study of 36 patients with serologically proven Chagas disease who were initially evaluated with Tc-99m-Sestamibi MPS at rest and during physical exercise and who had the nuclear examination repeated after a mean period of 5.6 years $^{50}$. Of the 36 patients, $20(56 \%)$ exhibited reversible ischemic myocardial perfusion defects involving an average of $10.2 \% \pm 9.7 \%$ of the LV area, as determined by the SPECT technique. A topographic association between the presence of ischemia in the initial evaluation and the development of myocardial fibrosis was suggested by the results, as among the 47 segments presenting reversible perfusion defects in the initial study, $32(68 \%)$ progressed to perfusion defects at rest, and of the 469 segments not showing reversibility in the initial study, only $41(8.7 \%)$ had the same progression. The individual increase in the perfusion defect area at rest (possibly indicating the presence of fibrosis) was significantly correlated with the corresponding reduction in $\mathrm{LV}$ ejection fraction (with a mean decrease over time in the entire group of patients from $55 \% \pm 11 \%$ to $50 \% \pm 13 \%$ ). Hence, in this longitudinal study, the deterioration of LV systolic function over time was associated with both the presence of reversible ischemic defects at the initial assessment and an increase in the extent of irreversible perfusion defects during follow-up ${ }^{50}$. In patients with Chagas cardiomyopathy selected for malignant ventricular arrhythmia, perfusion defects were also predominant in areas from which the reentrant circuits frequently arise ${ }^{51}$.

Although the mentioned studies have shown that the detection of microvascular myocardial ischemia is associated with a worse outcome regarding ventricular function, the role of MPS in the detection of early myocardial involvement in patients with the indeterminate form of chronic Chagas disease is more unclear. A recent study found normal myocardial perfusion in all 18 patients with the indeterminate form of Chagas disease who were submitted to stress-rest MPS with Tc-99m- Sestamibi ${ }^{52}$.

Because the tracer used in most previously mentioned studies $^{41,48,49}$ was 201-thallium (Figure 1 depicts an illustrative example), its accumulation and retention could be influenced by

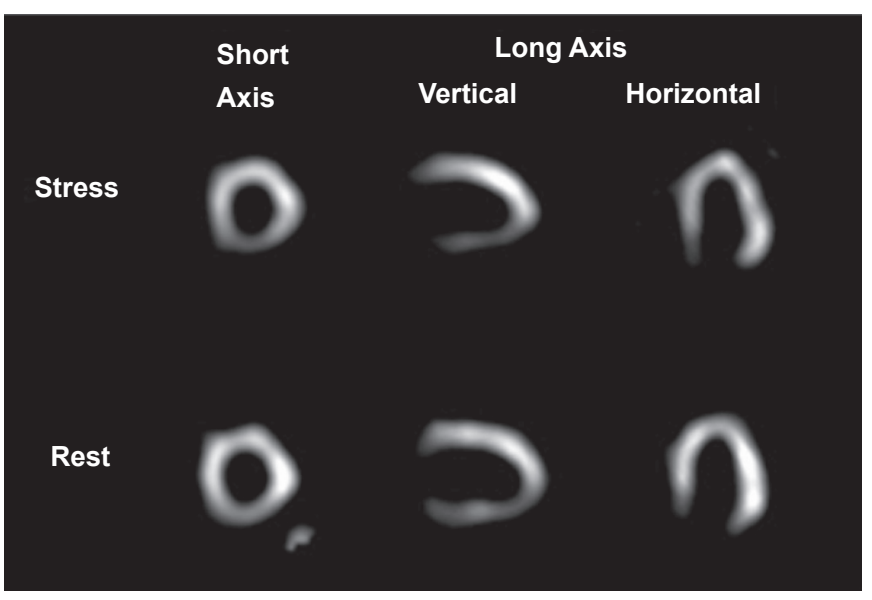

FIGURE 1 - Representative tomographic slices of stress-rest 201-thallium myocardial perfusion scintigraphy of a Chagas disease patient (male, 48 years old) presenting chest pain and normal epicardial coronary arteries. A reversible perfusion defect is observed in the inferior wall and in part of the apical, septal and posterior-lateral walls. The left ventricular ejection fraction was $36 \%$, and hypokinesia of the inferior and posterior-lateral walls was detected by echocardiogram. 
cardiomyocyte metabolic derangements related to the underlying inflammatory process. Hence, the scintigraphic defects described in the previous studies might not represent true perfusion abnormalities. This alternative possibility is supported by the frequent occurrence of reverse redistribution defects predominating in LV regions with normal or mildly impaired wall motion in those studies. However, myocardial perfusion was also evaluated in 18 chronic Chagas' heart disease patients with recurrent chest pain that was severe enough to warrant coronary angiography using an exclusive perfusion tracer, 99m-technetium-labeled microspheres, injected into the LV cavity ${ }^{44}$. All patients presented normal epicardial coronary arteries. Ten of the 18 patients exhibited extensive perfusion defects in 49 (39\%) of $126 \mathrm{LV}$ segments. In total, $19(40 \%)$ of these segments with perfusion defects had severely impaired wall motion, most likely corresponding to extensive fibrosis. The remaining $60 \%$ of the segments with perfusion defects had normal or mildly reduced wall motion. Thus, this investigation clearly showed marked resting myocardial perfusion abnormalities preceding the appearance of any wall motion impairment ${ }^{44}$

More recently, the use of magnetic resonance imaging (MRI) to examine patients with CCC has been reported ${ }^{53,54}$. In one study, 51 patients with CCC were investigated by MRI, including techniques of late contrast enhancement, for the detection of myocardial fibrosis. Myocardial fibrosis was found in $20 \%$ of 15 patients with the indeterminate form and in $84.6 \%$ of 26 patients with overt Chagas heart disease. The distribution of fibrosis was atypical for CAD and predominated in the midwall and subepicardial portions of the LV walls, encompassing multiple coronary territories. This pattern was compatible with myocardial fibrosis associated with myocardial ischemia secondary to microvascular derangement and chronic myocarditis, as also documented in hypertrophic and dilated cardiomyopathy ${ }^{55,56}$. Similar findings and interpretation were reported by another study, which investigated 67 Chagas disease patients. Late enhancement was detected in $23.9 \%$ of the patients, with a highly heterogeneous distribution: subendocardial in $26.8 \%$, midwall in $14 \%$, subepicardial in $22.6 \%$ and transmural in $36 \%{ }^{54}$.

\section{PATHOPHYSIOLOGICAL CONSEQUENCES OF CORONARY MICROVASCULAR PERFUSION DISTURBANCES AND THERAPEUTIC PERSPECTIVES ON CHAGAS DISEASE}

On the basis of these clinical investigations and the background information from the pathological and experimental studies discussed, it is reasonable to hypothesize that myocardial perfusion derangements could contribute to the development of the characteristic segmental LV dysfunction observed in the chronic phase of Chagas heart disease. This pathophysiological mechanism may be similar to the chronic hyperperfusion that causes hibernating myocardium in patients with longstanding coronary artery disease. A corollary is that at least in the early stages of the disease, wall motion abnormalities due to ischemia may be reversible in Chagas patients. This concept is compatible with evidence from studies showing improvement in LV function in Chagas heart disease patients who received acute or chronic administration of dipyridamole ${ }^{57}$ and isosorbide dinitrate ${ }^{58}$. However, these studies obtained no direct evidence indicating that the improvement in LV function was due to the relief of myocardial ischemia. In fact, the associated changes in ventricular loading conditions caused by the administration of dipyridamole and nitrate might have contributed to the improvement in ventricular performance. Only one study directly addressed the question of hibernating myocardium in CCC. The study was performed using post-extrasystolic potentiation, which is commonly observed during radiologicalcontrast left ventriculography, and showed that most myocardial areas with impaired wall motion indeed had a contractile reserve; that is, these areas were viable ${ }^{59}$. However, the hypothesis that hypokinetic areas of viable myocardium, unmasked through post-extrasystolic potentiation, would be predominant in regions exhibiting scintigraphic, reversible (ischemic) perfusion defects, was not confirmed by the results of the study ${ }^{60}$.

Thus, although scientifically attractive, the hypothesis of chronic myocardial ischemia in Chagas' cardiomyopathy awaits a direct demonstration of benefit to be derived from the long-term administration of drugs acting upon the microcirculation, with a significant impact on the outcome of Chagas disease patients with angina-like symptoms. One such study is currently ongoing, with the primary objective of testing the hypothesis that the prolonged administration of verapamil and acetylsalicylic acid to Chagas patients with normal epicardial coronary arteries, chest pain and reversible ischemic perfusion defects at baseline examination will lead to a reduction in the extent and intensity of the perfusion abnormalities and a mitigation of the angina-like symptoms ${ }^{61}$.

Finally, as the pathological changes found in the microvasculature of patients with chronic Chagas disease are linked either directly or indirectly to the persistence of $T$. cruzi, it is reasonable to speculate that therapy aimed at eliminating the parasite could prevent or ameliorate the microcirculatory disturbances. This hypothesis is reasonable, despite recent guidelines being evasive in recommending trypanocidal treatment for patients in the chronic phase of Chagas disease ${ }^{62}$.

\section{CONFLICT OF INTEREST}

The authors declare that there is no conflict of interest.

\section{REFERENCES}

1. Marin-Neto JA, Cunha-Neto E, Maciel BC, Simões MV. Pathogenesis of chronic Chagas heart disease. Circulation 2007; 115: 1109-1123.

2. Rossi MA, Tanowitz HB, Malvestio LM, Celes MR, Campos EC, Blefari V, et al. Coronary microvascular disease in chronic Chagas cardiomyopathy Including an overview on history, pathology, and other proposed pathogenic mechanisms. PLoS Negl Trop Dis 2010; 4:e674.

3. Vianna G. Contribuição para o estudo da anatomia patológica da moléstia de Chagas. Mem Inst Oswaldo Cruz 1911; 3:276-294.

4. Torres CM. Arteriosclerosis of the fine arterial branches of the myocardium (Chagas' coronaritis) \& focal myocytolysis in chronic Chagas' heart disease. Hospital (Rio de Janeiro) 1958; 54:597-610. 
5. Torres CM. Miocitólise e fibrose do miocárdio na doença de Chagas. Mem Inst Oswaldo Cruz 1960; 58:161-182.

6. Jörg ME. Tripanosomiasis cruzi; anarquia angiotopográfica por descapilarización mesenguimorreactiva: cofactor patogénico de la miocardiopatia crónica. Pren Med Argent 1974; 61:94-106.

7. Ferreira CS, Lopes ER, Chapadeiro E, Silva Neto IJ, Oliveira Almeida H, Souza WF. Coronariografia post mortem na cardite chagásica crônica: correlação anátomo-radiológica. Arq Bras Cardiol 1980; 34:81-86.

8. Ferrans VJ, Milei J, Tomiata Y, Storino RA. Basement membrane thickening in cardiac myocytes and capillaries in chronic Chagas' disease. Am J Cardiol 1988; 61:1137-1140.

9. Laranja FS, Dias E, Nóbrega C, Miranda A. Chagas' disease: a clinical, epidemiological and pathological study. Circulation 1956; 1035-1060.

10. Köberle F. Cardiopatia Chagásica. Hospital 1958; 53:311-346.

11. Ferreira CS, Lopes ER, Chapadeiro E, Almeida HO, Souza WF, SilvaNeto JJ. Coronariografia post-mortem na cardite chagásica crônica. Correlação anátomo-radiológica. Arq Bras Cardiol 1980; 34:81-86.

12. Higuchi ML, Brito T, Parzianello LC, Fukasawa S, Ramires JA. Severe arteriolar dilatation and ischemic lesions in chronic Chagas' cardiopathy: a 3D confocal laser microscopic study. J Am Coll Cardiol 1998; 31:382.

13. Morris AS, Tanowitz HB, Wittner M, Bilezikian JP. Pathophysiological insights into the cardiomyopathy of Chagas' disease. Circulation 1990; 82:1900-1909.

14. Rossi MA. Microvascular changes as a cause of chronic cardiomyopathy in Chagas'disease. Am Heart J 1990; 120:233-236.

15. Higuchi ML, Fukasawa S, De Brito T, Parzianello LC, Bellotti G, Ramires JA. Different microcirculatory and interstitial matrix patterns in idiopathic dilated cardiomyopathy and Chagas'disease: a three dimensional confocal microscopy study. Heart 1999; 82:279-285.

16. Oliveira JAM. Heart aneurysm in Chagas' disease. Rev Inst Med Trop S Paulo 1998; 40:301-307.

17. Oliveira JSM, Mello de Oliveira JA, Frederigue Jr U, Lima Filho EC. Apical aneurysm of Chagas's heart disease. Br Heart J 1981; 46:432-437.

18. Oliveira JSM, Santos JCM, Muccillo G, Ferreira AL. Increased capacity of the coronary arteries in chronic Chagas'heart disease: further support for the neurogenic pathogenesis concept. Am Heart J 1985; 109: 304-308.

19. Simões MV, Bromberg-Marin G, Antloga CM, Maciel BC, Marin-Neto JA. Tonus e diâmetro arterial coronário não se correlacionam com o grau de denervação autonômica em pacientes com cardiopatia chagásica crônica. Rev Bras Cardiol Invas 2008; 16:70-76.

20. Mello de Oliveira JA. Observações sobre a histoquímica de algumas enzimas do miocárdio na fase crônica da infecção experimental pelo Trypanosoma cruzi, Chagas, 1909, em ratos Wistar. Rev Goiana Med 1976; 22:1-65.

21. Rossi MA, Gonçalves S, Ribeiro-dos-Santos R. Experimental Trypanosoma cruzi cardiomyopathy in BALB/c mice: the potential role of intravascular platelet aggregation in its genesis. Am J Pathol 1984; 114:209-216.

22. Rossi MA, Carobrez SG. Experimental Trypanosoma cruzi cardiomyopathy in BALB/c mice: histochemical evidence of hypoxic changes in the myocardium. Br J Exp Pathol 1985; 66:155-160.

23. Factor SM, Cho S, Wittner M, Tanowitz HB. Abnormalities of the coronary microcirculation in acute murine Chagas' disease. Am J Trop Med Hyg 1985; 34:246-253.

24. Figueiredo F, Marin-Neto JA, Rossi MA. The evolution of experimental Trypanosoma cruzi cardiomyopathy in rabbits: further parasitological, morphological and functional studies. Int J Cardiol 1986; 10:277-290.

25. Rossi MA. Aortic endothelial cell changes in the acute septicemic phase of experimental Trypanosoma cruzi infection in rats: scanning and transmission electron microscopy study. Am J Trop Med Hyg 1997; 57:321-327.

26. Andrade ZA, Andrade SG, Correa R, Sadigursky M, Ferrans VJ. Myocardial changes in acute Trypanosoma cruzi infection. Ultrastructural evidence of immune damage and the role of microangiopathy. Am J Path 1994; 144:1403-1411.

27. Scharfstein J, Andrade D. Infection-associated vasculopathy in experimental chagas disease pathogenic roles of endothelin and kinin pathways. Adv Parasiol 2011; 76:101-27.

28. Morris SA, Tanowitz HB, Makman M. Trypanosoma cruzi: alteration of cAMP metabolism following infection of human endothelial cells. Exp Parasit 1992; 74:69-76.

29. Tanowitz HB, Huang H, Jelicks LA, Chandra M, Loredo ML, Weiss LM, et al. Role of endothelin 1 in the pathogenesis of chronic chgasic heart disease. Infec Immun 2005; 73:2496-2503.

30. Libby P, Alroy J, Pereira MEA. A neuraminidase from Trypanosoma cruzi removes sialic acid from the surface of mammalian myocardial and endothelial cells. J Clin Invest 1986; 77:127-135.

31. Tanowitz HB, Burns ER, Sinha KA, Kahn NN, Morris SA, Factor SM, et al. Enhanced platelet adherence and aggregation in Chagas' heart disease: a potential pthogenic mechanism for cardiomyopathy. Am J Trop Med Hyg 1990; 43:274-281.

32. Huang H, Calderon TM, Berman JW, Braunstein VL, Weiss LM, Wittner M, et al. Infection of endothelial cells with Trypanosoma cruzi activates NF-kappaB and induces vascular adhesion molecule expression. Infec Immun 1999; 67:5434-5440.

33. Morris SA, Weiss LM, Factor SM, Bilezikian JP, Tanowitz H, Wittner $\mathrm{M}$, et al. Verapamil ameliorates clinical, pathological and biochemical manifestations of the experimental chagasic cardiomyopathy in mice. J Am Coll Cardiol 1989; 14:782-789.

34. Tanowitz HB, Kaul DK, Chen B, Morris SA, Factor SM, Weiss LM, et al. Compromised microcirculation in acute murine Trypanosoma cruzi infection. J Parasit 1996; 82:124-130.

35. Ferreira V, Molina MC, Schwaeble W, Lemus D, Ferreira A. Does Trypanosoma cruzi calreticulin modulate the complement system and angiogenesis? Trends Parasitol 2005; 21:169-174.

36. Marin-Neto JA, Rassi Jr A, Simões MV, Maciel BC, Schmidt A. Chagas heart disease. In: Yusuf S, Cairns JA, Camm AJ, Fallen EL, Gersh BJ, editors. Evidence-Based Cardiology. $3^{\text {rd }}$ edition. Chapter 51; 2010. p. $823-841$.

37. Feit A, El-Sherif N, Korostoff S. Chagas' disease masquerading as coronary artery disease. Arch Intern Med 1983; 143:144-145.

38. Simões MV, Mello-Ayres E, Attab-Santos JL, Schmidt A, Pintya AO, Maciel BC, et al. Detection of myocardial ischemia in Chagas' heart disease patients with angina-like symptoms by the effort test and holter monitoring. Arq Bras Cardiol 1993; 60:315-319.

39. Hammermeister KE, Caeiro T, Crespo E, Palmero H, Gibson DG. Left ventricular wall motion in patients with Chagas' disease. Br Heart J 1984; 51:70-76.

40. Arreaza N, Puigbó JJ, Acquatella H, Casal H, Giordano H, Valecillos R, et al. Radionuclide evaluation of left ventricular function in chronic Chagas' cardiomyopathy. J Nucl Med 1983; 24:563-567.

41. Hagar JM, Rahintoola SH. Chagas' heart disease in the United States. N Engl J Med 1991; 325:763-768.

42. Vianna LG, Campos GP, Magalhães AV. Myocardial infarct without coronary obstruction associated with chronic Chagas cardiopathy. Arq Bras Cardiol 1979; 33:41-47.

43. Torres FW, Acquatella H, Condado JA, Dinsmore R, Palácios IF. Coronary vascular reactivity is abnormal in patients with Chagas' disease. Am Heart J 1995; 129:995-1001.

44. Marin-Neto JA, Simões MV, Ayres-Neto EM, Attab-Santos JL, Gallo Jr L, Amorim DS, et al. Studies of the coronary circulation in Chagas' heart disease. São Paulo Medical Journal 1995; 113:826-834.

45. Kuschnir E, Kustich F, Epelman M, Santamarina N, Podio RB. Valoration de fluxo miocardico con Rb 86, en pacientes con cardiopatia chagasica, con insuficiencia coronaria y en controles normales. Parte 1: Estudios basales. Arq Bras Cardiol 1974; 27:187-196. 
46. Kuschnir E, Kustich F, Epelman M, Santamarina N, Podio RB. Valoration de fluxo miocardico con $\mathrm{Rb} 86$, en pacientes con cardiopatia chagasica, con insuficiencia coronaria y en controles normales. Parte 2 Respuesta al ejercicio y a la cardiotonificación aguda. Arq Bras Cardiol 1974; 27:721-732.

47. Castro R, Kuschnir E, Sgammini H. Evaluacion de la performance cardíaca y perfusion miocárdica com radiotrazadores en la cardiopatia chagásica crônica. Rev Fed Arg Cardiol 1988; 17:226-231.

48. Marin-Neto JA, Marzullo P, Marcassa C, Gallo-Junior L, Maciel $\mathrm{BC}$, Bellina $\mathrm{CR}$, et al. Myocardial perfusion abnormalities in chronic Chagas'disease as detected by thallium-201 scintigraphy. Am J Cardiol 1992; 69:780-784.

49. Simões MV, Pintya AO, Bromberg-Marin G, Sarabanda AV, Antloga CM, Pazin-Filho A, et al. Relation of regional sympathetic denervation and myocardial perfusion disturbance to wall motion impairment in Chagas' cardiomyopathy. Am J Cardiol 2000; 86:975-981.

50. Hiss FC, Lascalla TF, Maciel BC, Marin-Neto JA, Simões MV. Changes in myocardial perfusion correlate with deterioration of left ventricular systolic function in chronic Chagas'cardiomyoparthy. J Am Coll Cardiol Img 2009; 2:164-172.

51. Sarabanda AVL, Sosa E, Simões MV, Figueiredo GL, Pintya AO, MarinNeto JA. Ventricular tachycardia in Chagas' disease: a comparison of clinical, angiographic, electrophysiologic and myocardial perfusion disturbances between patients presenting with either sustained or nonsustained forms. Int J Cardiol 2005; 102:9-19.

52. Abuhid IM, Pedroso ERP, Rezende NA. Scintigraphy of the detection of myocardial damage in the indeterminate form of Chagas disease. Arq Bras Cardiol 2010; 95:30-34.

53. Rochitte CE, Oliveira PF, Andrade JM, Ianni BM, Parga JR, Ávila LF, et al. Myocardial delayed enhancement by magnetic resonance Imaging in patients with Chagas' disease - A marker of disease severity. J Am Coll Cardiol 2005; 46:1553-1558.

54. Regueiro A, García-Álvarez A, Sitges M, Ortiz-Pérez JT, De Caralt MT, Pinazo MJ, et al. Myocardial involvement in Chagas disease: insights from cardiac magnetic resonance. Int J Cardiol 2011; 165:107-112.
55. Sotgia B, Sciagrà R, Olivotto I, Casolo G, Rega L, Betti I, et al. Spatial relationship between coronary microvascular dysfunction and delayed contrast enhancement in patients with hypertrophic cardiomyopathy. J Nucl Med 2008; 49:1090-1096.

56. Wang L, Yan C, Zhao S, Fang W. Comparison of (99m)Tc-MIBI SPECT/18F-FDG PET imaging and cardiac magnetic resonance imaging in patients with idiopathic dilated cardiomyopathy: assessment of cardiac function and myocardial injury. Clin Nucl Med 2012; 37:1163-1169.

57. Kuschnir E, Sgammini H, Castro R, Evequoz C, Ledesma R. Miocardiopatia chagásica crônica: effectos del dipiridamol sobre la dinâmica ventricular. Arq Bras Cardiol 1983; 41:373-378.

58. Marin-Neto JA, Souza ACS, Maciel BC, Gallo-Junior L, Iazigi N. Avaliação angiocardiográfica nuclear do efeito do dinitrato de isosorbitol em pacientes chagásicos. Arq Bras Cardiol 1988; 51:367-371.

59. Brandão JMM, Miziara A, Figueiredo GL, Lima Filho MO, Ayres-Neto EM, Marin-Neto JA. Potenciação pós-extrassistólica na cardiopatia chagásica crônica. Estudo com ventriculografia de contraste radiológico. Arq Bras Cardiol 2005; 84: 376-380.

60. Miziara A, Marin-Neto JA, Marchini JFM, Figueiredo GL, Pintya AO, Simões MV, et al. Discinesia ventricular esquerda reversível identificada por potenciação pós-extrassistólica em miocardiopatia chagásica crônica não é causada por hibernação miocárdica. Rev Bras Cardiol Invasiva 2009; 17:358-368.

61. Macedo LGR, Lemos DC, Lago IM, Figueiredo GL, Lima Filho MO, Schmidt A, et al. Base racional e plano de estudo prospectivo para avaliar o efeito de terapêutica antiplaquetária e vasodilatadora microcirculatória em pacientes com cardiopatia chagásica crônica e distúrbios microvasculares coronários. Rev Bras Cardiol Invasiva 2012; 20:82-88.

62. Andrade JP, Marin-Neto JA, Paola AA, Vilas-Boas F, Oliveira GM, Bacal F, et al. Sociedade Brasileira de Cardiologia. I Latin American guidelines for the diagnosis and treatment of Chagas cardiomyopathy. Arq Bras Cardiol 2011; 97 (supl III):1-48. 